\title{
Treatment of surface water using cold plasma for domestic water supply
}

\author{
Dung Van Nguyen ${ }^{1^{\dagger}}$, Phong Quoc Ho $^{2}$, Toan Van Pham ${ }^{3}$, Tuyen Van Nguyen ${ }^{3}$, Lavane Kim ${ }^{3}$ \\ ${ }^{1}$ Department of Electrical Engineering, Cantho University, Cantho 941, Vietnam \\ ${ }^{2}$ Department of Chemical Engineering, Cantho University, Cantho 941, Vietnam \\ ${ }^{3}$ Department of Environmental Engineering, Cantho University, Cantho 941, Vietnam
}

\begin{abstract}
This paper presents the results of using cold plasma to treat surface water for domestic use purpose. Experimental results showed that cold plasma was an effective method for destroying bacteria in water. After treatment with cold plasma, concentration of coliform and Escherichia coli dramatically reduced. Besides, cold plasma significantly removed water odor, increased dissolved oxygen and decreased the concentration of chemical oxygen demand. However, cold plasma significantly raised the concentration of nitrite and nitrate. Other disadvantages of treating with cold plasma were conductivity increase and $\mathrm{pH}$ reduction. Pretreatment steps of coagulation, flocculation, sedimentation and sand filtration followed by disinfection with cold plasma exhibited a high efficiency in surface water treatment. All parameters of surface water after treatment by using the prototype satisfied with the allowance standard of domestic water quality.
\end{abstract}

Keywords: Cold plasma, High voltage, Hydroxyl radical, Ozone, Water treatment

\section{Introduction}

Cold plasma is green technology and has been studied for water treatment [1-6]. The cold plasma was produced with numerous methods [7]. Among these methods, dielectric barrier discharges (DBD) and corona discharges (CD) have shown the highest efficiency in water treatment [7]. DBD method is simple, reliable and suitable with water treatment in small scale [2]. For water treatment, DBD was commonly generated with the coaxial electrode system. When cold plasma is formed due to DBD, high energetic free electrons, ultraviolet (UV) light and variety of active species are produced in the electrode gap [8]. Among these species, ozone is one of the most chemically stable and active species. The reactions to generate ozone are expressed in Eq. (1) and (2). Ozone reacts with water molecules to create hydroxyl radicals as Eq. (3). In addition, energetic free electrons may collide with water molecules to yield more hydroxyl radicals as Eq. (4). The interaction between cold plasma and water leads to the formation of oxidizing species (e.g., $\mathrm{OH}^{\bullet}, \mathrm{H}^{\bullet}, \mathrm{O}^{\bullet}, \mathrm{O}_{3}, \mathrm{H}_{2} \mathrm{O}_{2}$, etc.) in water [8]. The synergistic effect of energetic free electrons, UV, oxidizing species and intense electric

This is an Open Access article distributed under the term of the Creative Commons Attribution Non-Commercial License (http://creativecommons.org/licenses/by-nc/3.0/) which permits unrestricted non-commercial use, distribution, and reproduction in any medium, provided the original work is properly cited.

Copyright (C) 2019 Korean Society of Environmental Engineers field result in high efficiency in water treatment of cold plasma.

$$
\begin{gathered}
\mathrm{O}_{2}+\bar{e} \rightarrow \mathrm{O}+\mathrm{O}+\bar{e} \\
\mathrm{O}+\mathrm{O}_{2} \rightarrow \mathrm{O}_{3} \\
3 \mathrm{O}_{3}+\mathrm{H}_{2} \mathrm{O} \rightarrow 2 \mathrm{OH}^{\bullet}+4 \mathrm{O}_{2} \\
e^{-}+\mathrm{H}_{2} \mathrm{O} \rightarrow \mathrm{OH}^{\bullet}+\mathrm{H}^{\bullet}+e^{-}
\end{gathered}
$$

Cold plasma from DBD efficiently treated Escherichia coli (E. coli). With treatment duration of about $30 \mathrm{~min}$, the concentration of $E$. coli in water was reduced from $1.6 \times 10^{6} \mathrm{CFU} / \mathrm{mL}$ to $1 \times$ $10^{5} \mathrm{CFU} / \mathrm{mL}$ [9]. Similar results were obtained with previous studies $[3,10]$. The cold plasma was seen to significantly decrease the content of heavy metals, e.g., $\mathrm{Pb}, \mathrm{Cd}, \mathrm{Fe}$, and $\mathrm{Mn}$ [1]. Furthermore, the cold plasma decomposed organic compounds manifested by reducing concentration of chemical oxygen demand (COD) and 5-day biochemical oxygen demand $\left(\mathrm{BOD}_{5}\right)$ as well as water discolor $[2,3,10]$. Most studies have focused on using cold plasma to
Received June 23, 2018 Accepted October 4, 2018

${ }^{\dagger}$ Corresponding author

Email: nvdung@ctu.edu.vn

Tel: +84-966-738-919

ORCID: 0000-0001-6699-2776 
decompose organic compounds for wastewater treatment [4-6, 8]. Chlorination, ozonation and UV radiation have used in disinfection step for surface water treatment. However, chlorine was not effective against some types of pathogens such as Cryptosporidum and Giardia [11], and creates by-products named tirhalomethanes as well as bad odor in treated water [12]. Ozone efficiently inactivated microorganisms and decomposed organic compounds [13]. When combining with filtration, ozone can treat heavy metal ions [13]. However, ozonation forms $\mathrm{NO}_{2}^{-}$and $\mathrm{NO}_{3}^{-}$in treated water, and ozone leakage creates human toxicity. UV method showed high efficiency in bacteria inactivation without by-products formation in treated water [11]. However, UV cannot inactivate heterotrophic bacteria, Aeromonas and Flexibater [14]. It was seen that ozonation followed by UV irradiation can improve the efficiency of micro-biological inactivation [14]. Therefore, cold plasma composed of ozone, UV and high energetic free electrons was predicted to have high effectiveness in surface water treatment.

In Vietnam, there are quite a lot of places in rural areas or remote areas that have not yet been supplied with "clean water". Clean water is here implied that the quality of supply water meets the allowance standard regulated by the National technical regulation on domestic water quality in Vietnam, numbered with QCVN 02:2009/BYT. People in rural areas have used surface water from rivers after a simple treatment with coagulation/flocculation and sedimentation. Although water becomes more transparent with lower concentration of bacteria after these treatment steps, it still does not meet the allowance standard of domestic water quality. Therefore, a study on cold plasma for surface water treatment to develop suitable devices for using in a group of 3 or 4 households is an alternative option.

In this study, experiments were performed with two models. A small-scale model was used in laboratory to determine optimum operation parameters and evaluate the efficiency of the treatment process. A prototype with capacity of $6 \mathrm{~m}^{3} / \mathrm{d}$ was installed and tested in a household in an islet of Vinhlong province, Vietnam.

\section{Materials and Methods}

\subsection{Materials}

Distilled water samples of 15 liters were used for performing experiments of testing concentrations of ozone and active species $(\mathrm{OH}$, $\mathrm{O}_{3}$, etc.) in water. Hanna test kit (HI-38054) was employed to determine ozone concentration in water sample. The 2,2-diphenyl-1-picrylhydrazy (DPPH) purchased from Sigma-Aldrich was used to detect $\mathrm{OH}$, and the UV-VIS spectrometer (V730, Jasco) was applied to measure optical density of the samples in wavelength of $520 \mathrm{~nm}$.

For evaluating the effectiveness of water treatment by cold plasma, 15 liters of surface water collected from Cantho River was used. Aluminium sulfate (17\%) was used as a coagulating agent for coagulation/flocculation process.

\subsection{Experimental Setup and Procedure}

Fig. 1 shows the setup of the small-scale model. The coaxial electrode system was used. The inner electrode was made of stainless steel with outer diameter of $22 \mathrm{~mm}$. The outer electrode was made of aluminium foil of $0.08 \mathrm{~mm}$. A quartz tube having inner and outer diameters of $29 \mathrm{~mm}$ and $35 \mathrm{~mm}$, respectively was used as an insulating barrier. Due to the appearance of micro-discharges, cold plasma was formed between water layer and inner surface of the tube. At the edges of outer electrode, CD occurs due to a dramatic enhancement of electric field intensity created by the edge effect. A pump was used to supply air to the plasma chambers inside and outside the quartz tube to enhance ozone generation and the concentration of ozone dissolved in water. At the outside plasma chamber, ozone was generated because of interaction between CD and oxygen in air. The ozone generated at the outside chamber was conducted to a porous disk placed at the bottom of the storage tank for increasing the efficiency of ozone dissolution in water. To determine optimum operation parameters of the plasma chamber, two experiments were performed with the small-scale model. The $1^{\text {st }}$ experiment was used to determine the optimum applied voltage by varying the voltage in steps from $15 \mathrm{kV}$ to 18 $\mathrm{kV}$ at $2 \mathrm{~L} / \mathrm{min}$ of the water flow rate. The optimum water flow rate was determined with the $2^{\text {nd }}$ experiment by changing the water flow rate in steps of $0.5 \mathrm{~L} / \mathrm{min}$ from $2 \mathrm{~L} / \mathrm{min}$ to $3 \mathrm{~L} / \mathrm{min}$ at 18 $\mathrm{kV}$. Optimum operation parameters determined from these two experiments were used to operate the plasma chambers of the prototype. All experiments were repeated three times. The average value and standard deviation of water quality parameters were calculated from the experimental data.

Fig. 2(a) shows the block diagram of process used for the prototype of surface water treatment (Fig. 2(b)). Raw water from river is pumped to the reaction tank. At the same time, a coagulant (aluminium sulfate- $\mathrm{Al}_{2}(\mathrm{SO} 4)_{3}$ ) is filled into this tank by a metering pump

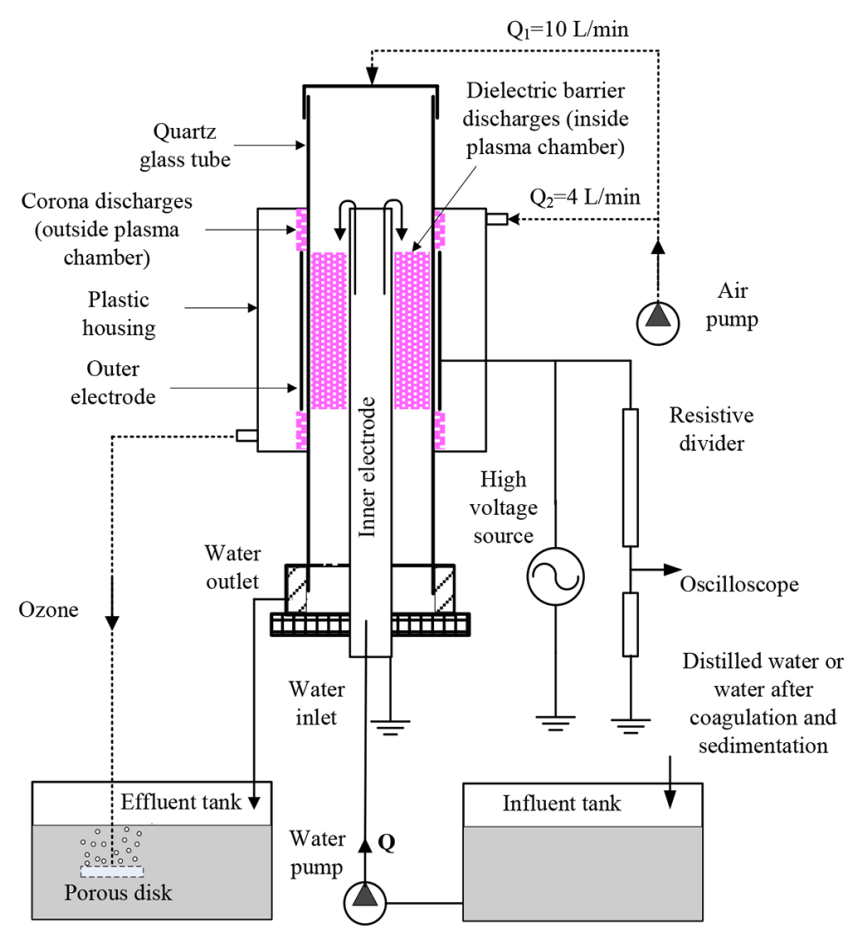

Fig. 1. Schematic showing the experimental set up of a small-scale model. 


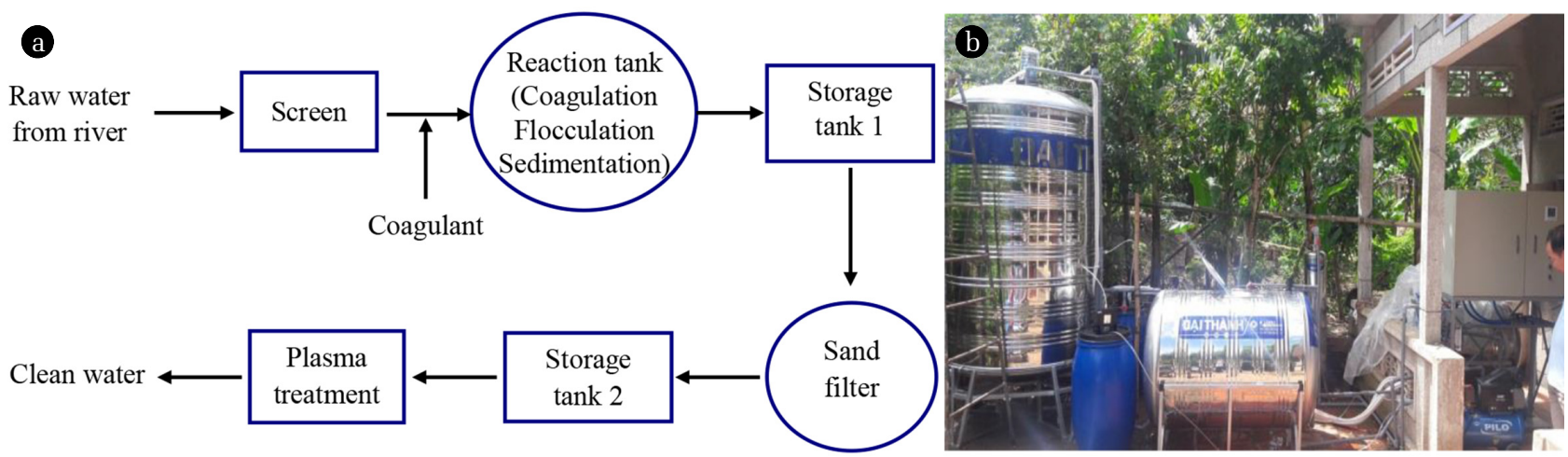

Fig. 2. (a) Block diagram of surface water treatment process and (b) the prototype of surface water treatment with cold plasma.

with a determined concentration of $100 \mathrm{mg}$ of $\mathrm{Al}_{2}\left(\mathrm{SO}_{4}\right)_{3}$ per 1 liter of water. A propeller is installed on the top of the reaction tank to well mix $\mathrm{Al}_{2}\left(\mathrm{SO}_{4}\right)_{3}$ with water and promote the flocculation process. The mixing time is $5 \mathrm{~min}$, and a predetermined time of $60 \mathrm{~min}$ is set up to finish the sedimentation process. After this process, water is forced through a sand filter with a flow rate of $20 \mathrm{~L} / \mathrm{min}$ to remove suspended residue. Then water with the flow rate of $7.5 \mathrm{~L} / \mathrm{min}$ is supplied to three plasma treatment columns for removing bacteria. After plasma treatment, clean water is stored in a stainless steel tank for domestic using. The prototype operates in batch of $3 \mathrm{~m}^{3}$ of water. Three samples of raw water and treated water were taken to analyze the value of quality parameters.

\subsection{Voltage Measurement}

The voltage applied to the electrode system was measured with a high voltage probe Pintek HVP 39-Pro coupled with an oscilloscope Tektronix TDS 2001C. Electrical power consumed by plasma chamber was measured with power meter MFM-383A.

\subsection{Ozone Measurement}

Ozone concentration in water was measured with the Hanna test kit (HI-38054). This test kit determines the ozone concentration with checker disc method. The reaction between ozone and the reagent causes a pink tint in the sample being proportional to the concentration of ozone.

\subsection{Active Species Measurement}

Active species generated by the plasma was commonly detected by using a stable radical, 2,2-diphenyl-1-picrylhydrazy (DPPH) [15, 16]. To determine the concentration of active species, $5 \mathrm{~mL}$ of sample after treatment with cold plasma was reacted with $5 \mathrm{~mL}$ of DPPH $0.1 \mathrm{mmol}$ in 30 minutes. After reaction, the color of solution changed from violet to light yellow and the solution was read by the UV-VIS spectrometer (Jasco-Japan) at wavelength of $520 \mathrm{~nm}$.

\subsection{Water Quality Parameter Measurement}

Quality parameters of water samples were analyzed with methods presented in the standard methods for the examination of water and wastewater [17]. These are $\mathrm{pH}$, Color, Odor, Turbidity, Residual chlorine, Ammonia, Total iron, Permanganate index, Hardness, Chloride, Fluoride, Arsenic, Total coliform and E. coli.

\section{Results and Discussion}

\subsection{Ozone and Active Species Generation}

\subsubsection{Effect of water flow rate}

The concentrations of ozone and active species in water were greatly affected by water flow rate as seen in Fig. 3. Both ozone and active species concentration linearly reduced with increasing the flow rate of water. As water flow rate increased from $1 \mathrm{~L} / \mathrm{min}$ to $5 \mathrm{~L} / \mathrm{min}$, ozone concentration decreased from $0.34 \mathrm{mg} / \mathrm{L}$ to $0.15 \mathrm{mg} / \mathrm{L}$. Simultaneously, active species also decreased from $7.6 \times 10^{-2}$ $\mathrm{mmol} / \mathrm{L}$ to $5.6 \times 10^{-2} \mathrm{mmol} / \mathrm{L}$. These results are due to interaction time between cold plasma and water layer reduced as increasing water flow rate, leading to a reduction in the concentrations of ozone and active species in water. In addition, an increase in water flow rate results in thicker water layer, leading to reduce the number of micro-discharges [2].

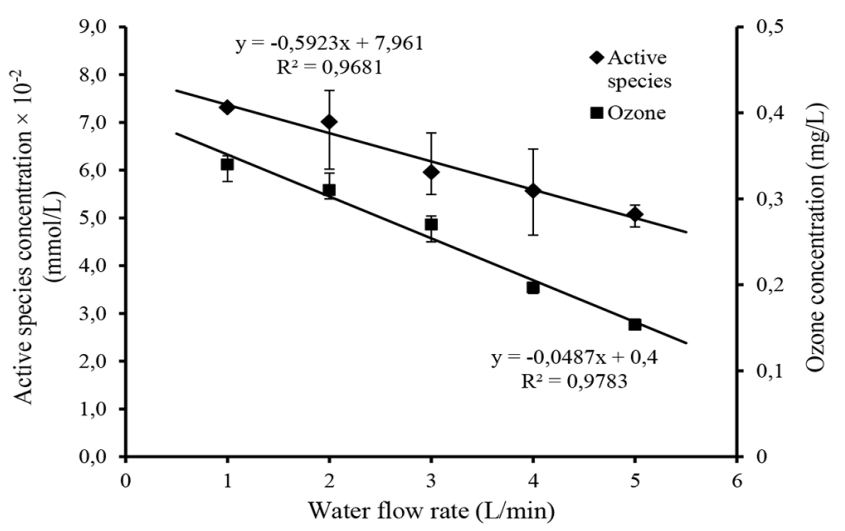

Fig. 3. Correlation between ozone, active species concentrations and water flow rate $(\mathrm{V}=18 \mathrm{kV})$.

\subsubsection{Effect of voltage magnitude}

Fig. 4 presents the relationship between the concentration of ozone and active species in water and applied voltage. An increase in the voltage magnitude resulted in a higher value of ozone concentration and the production of active species in water. The ozone concentration increased from $0.11 \mathrm{mg} / \mathrm{L}$ to $0.26 \mathrm{mg} / \mathrm{L}$ as the voltage was raised from $12 \mathrm{kV}$ to $18 \mathrm{kV}$, while active species concentration 


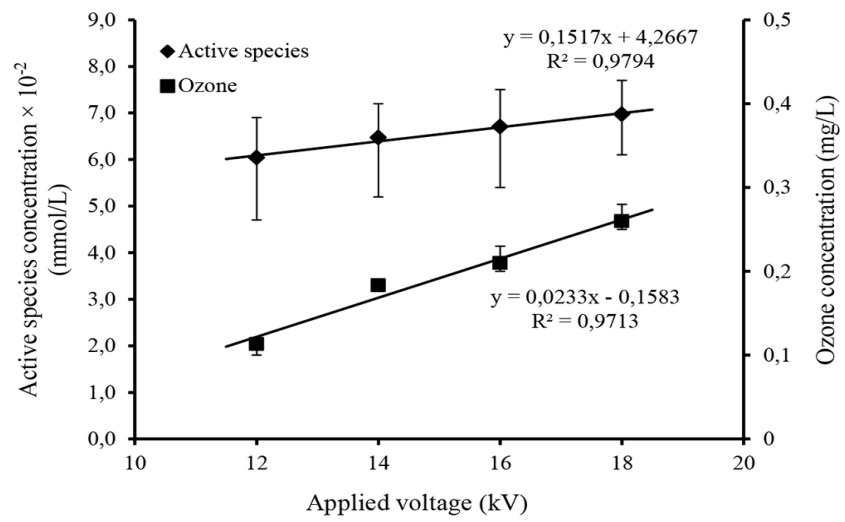

Fig. 4. Correlation between ozone concentration, ${ }^{\bullet} \mathrm{OH}$ concentration and voltage magnitude $(\mathrm{Q}=2 \mathrm{~L} / \mathrm{min})$.

increased by about $15 \%$ from $6.02 \times 10^{-2} \mathrm{mmol} / \mathrm{L}$ to $6.92 \times 10^{-2}$ $\mathrm{mmol} / \mathrm{L}$. This is because of higher applied voltage results in higher intensity and density of micro-discharges as well as higher energy of energetic electrons [8].

\subsection{Optimal Dose of Coagulant}

Prior testing surface water with a small-scale model, the Jar-test was performed to estimate the optimum concentration of aluminium sulfate $\mathrm{Al}_{2}\left(\mathrm{SO}_{4}\right)_{3}$ required. The $\mathrm{pH}$ value and turbidity of raw water were 7.6 and 27.7 NTU. The concentration of $\mathrm{Al}_{2}\left(\mathrm{SO}_{4}\right)_{3}$ was varied from $20 \mathrm{mg} / \mathrm{L}$ to $100 \mathrm{mg} / \mathrm{L}$. It was found that optimal value of $\mathrm{Al}_{2}\left(\mathrm{SO}_{4}\right)_{3}$ for coagulation and flocculation processes was $80 \mathrm{mg} / \mathrm{L}$, resulting in a $\mathrm{pH}$ value of 7.26 and turbidity of 2.2 NTU for treated water.

\subsection{Efficiency of Bacteria Treatment by Cold Plasma}

\subsubsection{Influence of applied voltage}

As mentioned above, UV, ozone and active species exist as long as cold plasma appears. The synergistic effect of these components is considered as the main reason to cause an effective destruction of bacteria by cold plasma. The concentration of $E$. coli in water sample before treatment was quite high $\left(9.3 \times 10^{3} \mathrm{MPN} / 100 \mathrm{~mL}\right)$. After pretreatment with coagulation/flocculation and sedimentation,

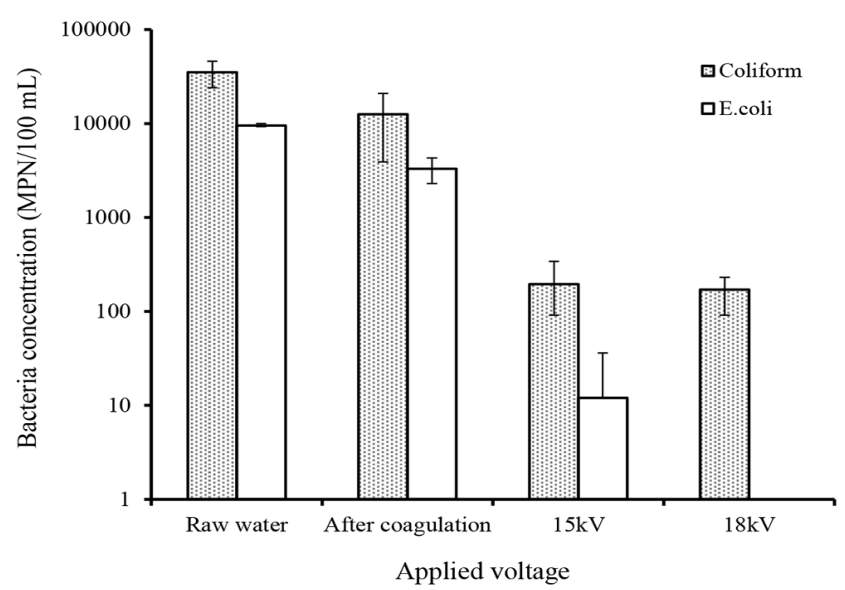

Fig. 5. Correlation between bacteria concentration and voltage magnitude $(\mathrm{Q}=2 \mathrm{~L} / \mathrm{min})$.
E. coli concentration decreased by $65.5 \%$ to a value of $3.3 \times 10^{3}$ MPN/100 mL. Then, water was treated with cold plasma and the results are shown in Fig. 5. The result showed that voltage magnitude forming cold plasma significantly affected the effectiveness of bacteria removing. Cold plasma reduced the concentration of $E$. coli by $99.8 \%$ and $100 \%$ for $15 \mathrm{kV}$ and $18 \mathrm{kV}$, respectively. For coliform, an increase in voltage raised the killing efficiency (98.4\% for 15 $\mathrm{kV}$; $98.7 \%$ for $18 \mathrm{kV}$ ). This indicates that higher applied voltage resulted in higher efficiency of bacteria destroying. This is because of an increase in applied voltage will raise the concentrations of ozone and active species (Fig. 4).

\subsubsection{Influence of water flow rate}

Fig. 6 shows how the water flow rate (Q) affects the efficacy of bacteria removing. The rate was varied in steps of $0.5 \mathrm{~L} / \mathrm{min}$ from $2 \mathrm{~L} / \mathrm{min}$ to $3 \mathrm{~L} / \mathrm{min}$. It was found that the flow rate of water significantly affected the effectiveness of the removal of bacteria. Among three water flow rates investigated, the water flow rate of $2.5 \mathrm{~L} / \mathrm{min}$ shows the highest efficiency of bacteria treatment. At this value of water flow rate, about $96.7 \%$ of coliform and $98.3 \%$ of $E$. coli were destroyed by cold plasma. It can be explained by the fact that consumed power of the plasma chamber reached the maximum value of $65 \mathrm{~W}$ at the rate of $2.5 \mathrm{~L} / \mathrm{min}$ while $55 \mathrm{~W}$ and $50 \mathrm{~W}$ were measured at the water flow rate of $2 \mathrm{~L} / \mathrm{min}$ and $3 \mathrm{~L} / \mathrm{min}$. Thus, at the water flow rate of $2.5 \mathrm{~L} / \mathrm{min}$ the gap between surface of water layer and surface of inner wall of the quartz tube may reach the optimum value for forming and maintaining cold plasma inside the electrode gap.

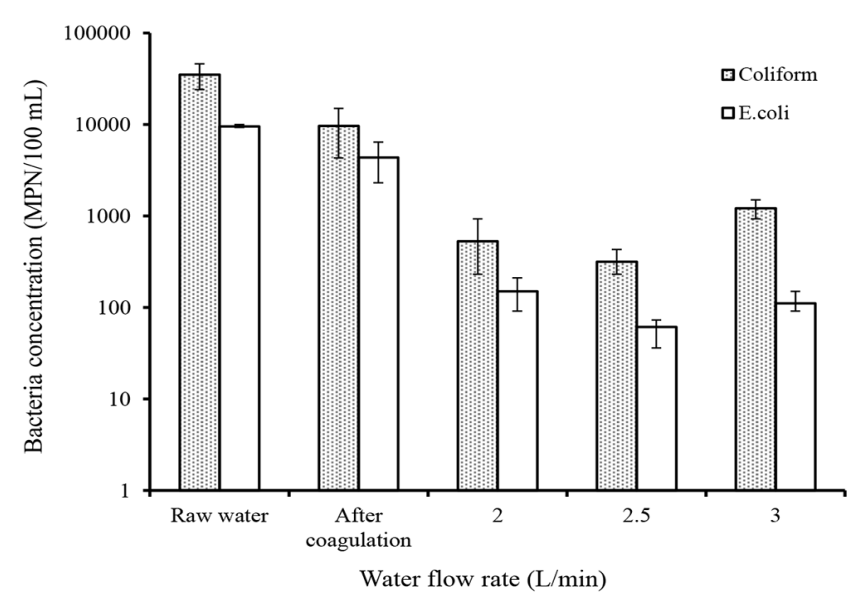

Fig. 6. Correlation between bacteria concentration and water flow rate $(\mathrm{V}=18 \mathrm{kV})$.

\subsection{Influence of Cold Plasma on Physicochemical Parameters of Water}

Physicochemical parameters of raw water and treated water are shown in Table 1. This experiment was performed with $18 \mathrm{kV}$ of applied voltage and $2.5 \mathrm{~L} / \mathrm{min}$ of water flow rate. These values of applied voltage and water flow rate result in the highest efficiency in bacteria removal as seen in Fig. 5 and 6. It is seen that cold plasma increased electrical conductivity (EC) by about $10 \%$, but slightly reduced $\mathrm{pH}$. This phenomenon is in agreement with previous 
Table 1. Physicochemical Parameters of Water

\begin{tabular}{lcccccc}
\hline Parameters & Unit & Raw water & $\begin{array}{c}\text { Treated water after coagulation/flocculation } \\
\text { and sedimetation }\end{array}$ & $\begin{array}{c}\text { Treated water after } \\
\text { cold plasma }\end{array}$ & $\begin{array}{c}\text { Treated water after } \\
\text { anion exchange resin }\end{array}$ \\
\hline EC & $\mathrm{mS} / \mathrm{cm}$ & $160 \pm 17.3$ & $236.7 \pm 15.3$ & $246.7 \pm 15.3$ & - \\
$\mathrm{pH}$ & - & $6.7 \pm 0.0$ & $7.5 \pm 0.06$ & $7.4 \pm 0.06$ & - \\
$\mathrm{DO}$ & $\mathrm{mg} / \mathrm{L}$ & $2.6 \pm 0.0$ & - & $5.3 \pm 0.6$ & - \\
Turbidity & $\mathrm{NTU}$ & $64.1 \pm 3.8$ & $13.6 \pm 1.1$ & $14.1 \pm 2.0$ & - \\
$\mathrm{COD}$ & $\mathrm{mg} / \mathrm{L}$ & $76.8 \pm 0.0$ & $26.9 \pm 0.0$ & $15.4 \pm 3.8$ & - \\
Nitrite & $\mathrm{mg} / \mathrm{L}$ & $0.03 \pm 0.0$ & $0.008 \pm 0.0$ & $0.7 \pm 0.18$ & $0.03 \pm 0.01$ \\
Nitrate & $\mathrm{mg} / \mathrm{L}$ & $0.44 \pm 0.0$ & $0.27 \pm 0.0$ & $2.0 \pm 0.52$ & $0.08 \pm 0.02$ \\
\hline
\end{tabular}

studies [4]. This can be explained by the formation of ions in water after treatment such as $\mathrm{H}^{+}, \mathrm{H}_{3} \mathrm{O}^{+}, \mathrm{NO}_{2}^{-}, \mathrm{NO}_{3}^{-}$. After treatment with cold plasma, dissolved oxygen (DO) significantly increased while COD greatly reduced. On the other hand, cold plasma showed a negative effect on turbidity. After treatment with cold plasma, the turbidity increased by about $4 \%$. This result is possibly explained by the fact that the dispersion of ozone with a porous disk will break large particles into numerous small ones. Thus, it is essential to add a filtration step after plasma treatment to remove small particles resulting in higher turbidity. In addition, another drawback of cold plasma was that it significantly enhanced nitrite and nitrate concentrations due to the presence of nitrogen in moist air inside plasma chambers. To reduce the concentrations of nitrite and nitrate in water sample after plasma treatment, anion exchange resin INDION-GS 3000 from Themax was investigated. The experiment was performed with $600 \mathrm{~mL}$ of GS 3000 contained in a plastic column of $1,000 \mathrm{~mL}$ and water flow rate of $2.5 \mathrm{~L} / \mathrm{min}$. It was observed that GS 3000 effectively removed nitrite and nitrate in water. Nitrite concentration was reduced from $0.7 \mathrm{mg} / \mathrm{L}$ to $0.03 \mathrm{mg} / \mathrm{L}$ ( $\sim 95.4 \%)$. At the same time, nitrate concentration was seen to decline by 96\% (from $2.0 \mathrm{mg} / \mathrm{L}$ to $0.08 \mathrm{mg} / \mathrm{L}$ ).

\subsection{Testing Data of the Prototype of Water Treatment System}

The prototype shown in Fig. 2(b) was operated with the treatment process presented in Fig. 2(a). aluminium sulfate $\left(\mathrm{Al}_{2}\left(\mathrm{SO}_{4}\right)_{3}\right)$ was used as a coagulating agent for coagulation and flocculation processes. Based on the Jar-test, the optimum dosage of $\mathrm{Al}_{2}\left(\mathrm{SO}_{4}\right)_{3}$ added into water was determined to be $100 \mathrm{mg} / \mathrm{L}$, and the measured values of turbidity and $\mathrm{pH}$ of water sample after the Jar-test were $2.5 \mathrm{NTU}$ and 7.1, respectively. The prototype consumed about $1.8 \mathrm{kWh} / \mathrm{m}^{3}$ of water treated.

Physical, chemical and bacteriological parameters of water samples before and after treatment by the prototype using cold plasma are presented in Table 2. It was found that after treatment, all quality parameters of water complied with the Vietnamese standard [18] and the WHO guideline [19]. The Vietnamese standard stipulates limits of quality criteria for domestic purposes but not for direct drinking or processing food.

It was seen that the prototype shows high efficiency in removing bacteria. It is about $99.9 \%$ and $96.4 \%$ for the removal of coliform and $E$. coli, respectively. This result is similar to previous reports on cold plasma studies [9, 10, 20], slow sand filtration [21], ceramic filtration [22], UV radiation [11] and ozonation [14]. The prototype

Table 2. Parameters of Water Prior and after Treatment

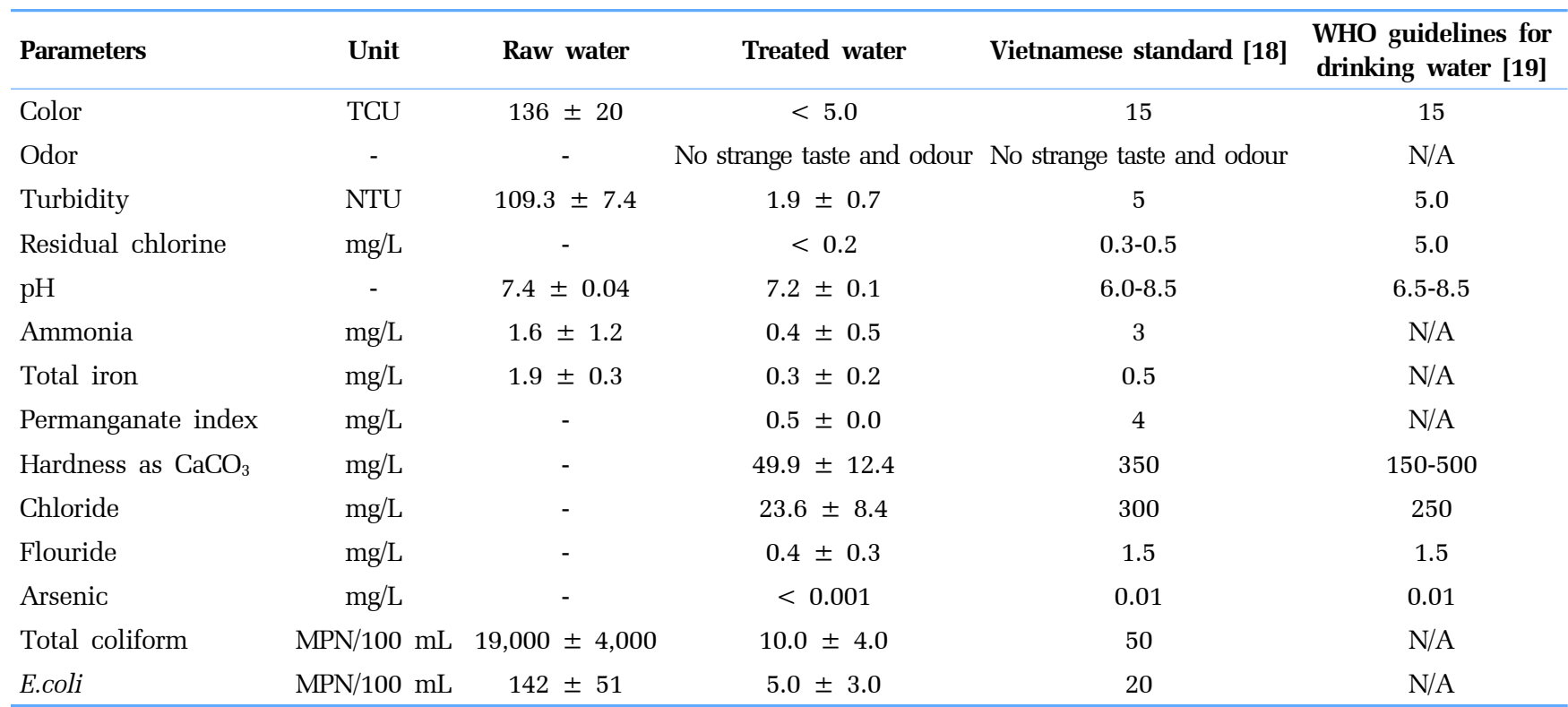


can remove about $75 \%$ of ammonia, which was oxidized to nitrate by ozonation [23]. In addition, the prototype removes $84 \%$ of total iron (from $1.9 \mathrm{mg} / \mathrm{L}$ to $0.3 \mathrm{mg} / \mathrm{L}$ ). This is similar to result received when groundwater was treated with ozone dose of $1.25 \mathrm{mg} / \mathrm{L}$ during 5 min [24]. Clearly, cold plasma combined with coagulation/flocculation process can treat varieties of pollutants in water as efficiently as other methods.

\section{Conclusions}

A combination between coagulation, flocculation, sedimentation and cold plasma shows a high efficiency in surface water treatment for domestic use purpose. The prototype successfully treats surface water for using indoor households in rural areas. The quality parameters of water after treatment with the prototype are in accordance with Vietnamese standard and WHO guidelines. However, cold plasma has a negative effect on nitrite and nitrate parameters. This problem can be effectively solved by using anion exchange resin.

\section{Acknowledgments}

This research is funded by Southwest program in Vietnam under grant number KHCN-TNB.ĐT/14-19/C02.

\section{References}

1. Grinevich VI, Kvitkova EY, Plastinia NA, Rybkin VV. Application of dielectric barrier discharge for waste water purification. Plasma Chem. Plasma Process. 2011;31:573-583.

2. Kuraica MM, Obradović BM, Manojlović D, Ostojić DR, Purić J. Application of coaxial dielectric barrier discharge for potable and waste water treatment. J. Ind. Eng. Chem. Res. 2006;45: 882-905.

3. Majeed WSA, Karunakaran E, Biggs C, Zimmerman WB. Application of cascade dielectric barrier discharge plasma atomizers for waste water treatment. In: 6th International Conference on Environmental Science and Technology. American Science Press; 2012.

4. Rong SP, Sun YB, Zhao ZH. Degradation of sulfadiazine antibiotics by water falling film dielectric barrier discharge. Chinese Chem. Lett. 2014;25:187-192.

5. Tichonovas M, Krugly E, Racys V, et al. Degradation of various textile dyes as wastewater pollutants under dielectric barrier discharge plasma treatment. Chem. Eng. J. 2013;229:9-19.

6. Valsero MH, Molina R, Schikora H, Müller M, Bayona JM. Removal of priority pollutants from water by means of dielectric barrier discharge atmospheric plasma. J. Hazard. Mater. 2013;262:
664-673.

7. Malik MA. Water purification by plasmas: Which reactors are most energy efficient? Plasma Chem. Plasma Process. 2010;30: 21-31.

8. Sarangapani C, Bourke P, Misra N, Milosavljevic V, O'Regan F. Pesticide degradation in water using atmospheric air cold plasma. J. Water Process Eng. 2016;9:225-232.

9. Velázquez VEQ, Callejas RL, Méndez BGR, et al. Pulsed power supply and coaxial reactor applied to E. coli elimination in water by PDBD. Rev. Int. Contam. Amb. 2013;29:25-31.

10. Taran VS, Krasnyj VV, Lozina AS, Shvets OM. Investigation of pulsed barrier discharge in water-air gap. J. Atom. Sci. Technol. (BAHT) 2013;83:249-251.

11. Hijnen WAM, Beerendonk EF, Medema GJ. Inactivation credit of UV radiation for viruses, bacteria and protozoan cysts in water: A review. Water Res. 2006;40:3-22.

12. Zhang X, Miner RA. Formation, adsorption and separation of high molecular weight disinfection by products resulting from chlorination of aquatic humic substances. Water Res. 2006;40: 221-230.

13. Camel V, Bermond A. The use of ozone and associated oxidation processes in drinking water treatment. Water Res. 1998;32: 3208-3222.

14. Sharrer MJ, Summerfelt ST. Ozonation followed by ultraviolet irradiation provides effective bacteria inactivation in a freshwater recirculating system. Aquacult. Eng. 2007;37:180-191.

15. Sharma OP, Bhat TK. DPPH antioxidant assay revisited. Food Chem. 2009;113:1202-1205.

16. Brand-Williams W, Cuvelier ME, Berset C. Use of a free radical method to evaluate antioxidant activity. LWT Food Sci. Technol. 1995;28:25-30.

17. APHA. APHA standard methods for the examination of water and wastewater. Washington D.C.; 2012.

18. MOH. QCVN 02:2009/BYT-National technical regulation on domestic water quality. 2009.

19. WHO. Guidelines for drinking-water quality. 2011.

20. Rashmei Z, Bornasi H, Ghoranneviss M. Evaluation of treatment and disinfection of water using cold atmospheric plasma. $J$. Water Health 2016;14:609-616.

21. Cotruvo JA, Craun GF, Hearne N. Providing safe drinking water in small systems, technology, operation and economics. CRC Press; 1999.

22. Lange J, Materne T, Gruner J. Do low cost ceramic water filters improve water security in rural South Africa? Drink. Water Eng. Sci. 2016;9:47-55.

23. Singer PC. Ozonation of ammonia in wastewater. Water Res. 1975;9:127-134.

24. Araby RE, Hawash S, Diwani GE. Treatment of iron and manganese in simulated groundwater via ozone technology. Desalination 2009;249:1345-1349. 